\title{
Flavanones from aerial parts of Cordia globosa (Jacq.) Kunth, Boraginaceae
}

\author{
Sâmia Andricia S. da Silva, ${ }^{* 1}$ Maria de Fátima Agra, ${ }^{2}$ Josean F. Tavares, ${ }^{2}$ \\ Emídio V. L. da-Cunha, ${ }^{2,3}$ José Maria Barbosa-Filho, ${ }^{2}$ Marcelo S. da Silva ${ }^{2}$
}

${ }^{1}$ Escola de Enfermagem e Farmácia, Universidade Federal de Alagoas, Cidade Universitária, 57072-970

Maceió-AL, Brazil.

${ }^{2}$ Laboratório de Tecnologia Farmacêutica, Universidade Federal da Paraíba, 58051-970 João Pessoa-PB, Brazil,

${ }^{3}$ Departamento de Farmácia e Biologia, Universidade Estadual da Paraíba, 58100-000 Campina Grande-PB, Brazil.

\begin{abstract}
RESUMO: "Flavanonas isoladas das partes aéreas de Cordia globosa (Jacq.) Kunth (Boraginaceae)". A análise fitoquímica das partes aéreas de Cordia globosa, coletadas no município de Picuí, PB, Brasil, resultou no isolamento e identificação estrutural da 7,4'-dimetilnarigenina $(0,025 \mathrm{~g})$ e eriodictiol $(0,015 \mathrm{~g})$. Estas duas flavanonas são as primeiras agliconas, desta classe, isoladas no gênero Cordia.
\end{abstract}

Unitermos: Cordia globosa, Boraginaceae, flavanonas, 7,4'-dimetilnarigenina, eriodictiol.

\begin{abstract}
The phytochemical analysis of aerial parts of Cordia globosa, collected in the Municipality of Picuí, State of Paraíba, Brazil, resulted in the isolation and structural identification of narigenin-4',7-dimethyl ether $(0.025 \mathrm{~g})$ and eriodictyol $(0.015 \mathrm{~g})$. These compounds are the first flavanones aglycones isolated from the genus Cordia.
\end{abstract}

Keywords: Cordia globosa, Boraginaceae, flavanones, narigenin-4',7-dimethyl ether, eriodictyol.

\section{INTRODUCTION}

The Boraginaceae family comprises about 2740 species distributed in 148 genera (Stevens, 2001). The genus Cordia is one of the most representatives of this family and the chemical characteristic in this genus is the presence of quinones known as cordiaquinones. However, flavonoids, terpenoids, carbohydrates, lipids and phenylpropanoids are also well reported for the genus (Silva, 2004).

Cordia globosa (Jacq.) Kunth is a shrub popularly known in Northeastern Brazil as 'maria-preta'. The decoction or infusion of the leaves of C. globosa is used in folk medicine for the treatment of the symptoms of rheumatism, painful menstruation and dyspepsia. In Jamaica, the tea of leaves is used by women against painful menstruation (Asprey \& Thornton, 1955). The leaves and the stems have spasmolytic activity on guinea pig ileum as well as on rabbit duodenum, and also was confirmed the vasodilator activity on isolated rats' hindquarter (Feng et al., 1962).

Previous studies reported the isolation of 7-methoxyflavone and 3',4',5,7-tetrahydroxy-3methoxyflavone (Silva et al., 2004) from the aerial parts and (1aS*, 1bS*, 7aS*, 8aS*)-4,5-dimethoxy-1a,7a-dimethyl1,1a, 1b,2,7,7a,8,8a-octahydrocyclopropa [3,4] cyclopenta [1.2b] naphthalene-3,6-dione and microphyllaquinone from the roots of C. globosa (Menezes et al., 2005). Twenty three and twenty six volatiles compounds were identified for the essential oils obtained from fresh leaves at the flowering and fructification stages, respectively. The bicyclogermacrene (22.7-13.1\%) and $\beta$-caryophyllene (11.9-11.6\%) were the majority constituents (Menezes et al., 2006). In another study, a total of 38 compounds were indentified from the oils obtained from steam and leaves. The main components in the stem oil were 1-endobourbonanol (20.2\%) and lynalyl butyrate (14.7\%) and in the leaves oil, the $\beta$-caryophyllene (39.0\%) and $\alpha$-humulene (12.1\%) were the majority (Oliveira et al., 2007).

\section{MATERIAL AND METHODS}

\section{General}

${ }^{1} \mathrm{H}$ and ${ }^{13} \mathrm{C}$ NMR (1D and 2D) were obtained on a MERCURY VARIAN spectrometer. ${ }^{1} \mathrm{H}$ and APT${ }^{13} \mathrm{C}$ NMR spectra were recorded in a $\mathrm{CDCl}_{3}(\mathrm{CG}-01)$ or $\mathrm{CD}_{3} \mathrm{OD}$ (CG-2) at 200 and $50 \mathrm{MHz}$, respectively. TMS was used as internal standard. TLC, on Si Gel $60 \mathrm{PF}_{254}$ ART 7749 (Merck) and column chromatography with Si Gel ART 7734 (Merck) or Sephadex-LH 20 (Pharmacia) were used. 


\section{Plant Material}

The aerial parts of Cordia globosa (Jacq.) Kunth were collected in March 2002 in the Municipality of Picuí, State of Paraíba, Brazil. A voucher specimen (AGRA 5185) has been deposited at the Herbarium Prof. Lauro Pires Xavier (JPB) in the Universidade Federal da Paraíba.

\section{Extraction, isolation and the structure elucidation}

The fresh aerial parts were dried at $40{ }^{\circ} \mathrm{C}$ for 72 $\mathrm{h}$ and after were grownded in a mechanical mill. Dried and powdered aerial parts $(10 \mathrm{~kg})$ from C. globosa were extracted with $\mathrm{EtOH}$ at room temperature for three days, five consecutive times. The alcoholic extract was then dried and the crude extract (300 g) obtained was taken up in $\mathrm{MeOH}: \mathrm{H}_{2} \mathrm{O}$ (7:3) and extracted successively with hexane, chloroform, ethyl acetate and n-buthanol.

The hexane $(37 \mathrm{~g})$ fraction was subjected to column chromatography packed with silica gel 60 and eluted with hexane, chloroform and methanol; 286 fractions of $50 \mathrm{~mL}$ were collected being analyzed and joined through analytical thin-layer chromatography (TLC). The sub-fraction 102-112 (0,320 g) was submitted to column chromatography packed with silica gel 60 an eluted with hexane, ethyl acetate and methanol gradient, resulting 61 fractions of $25 \mathrm{~mL}$ that were analyzed and joined through analytical TLC. The sub-fraction 14-21 after being recrystallized in chloroform showed itself as an incolor solid crystalline, yielding $0.025 \mathrm{~g}$ of the substance CG-01.

The fraction chloroformic (31 g) was subjected to column chromatography packed with silica gel 60 and eluted with hexane, ethyl acetate and methanol, from which 185 fractions of $50 \mathrm{~mL}$ were collected and the analyzed and joined through analytical TLC. The sub-fraction 159-165 (158 mg) was subjected to column chromatography packed with Sephadex LH 20 and eluted with chloroform:methanol (1:1) from which 22 fractions of $20 \mathrm{~mL}$ were collected and then analyzed and joined through analytical TLC. The sub-fraction 16-17 (30 mg) was subjected to column chromatography packed with Sephadex LH 20 and eluted with chloroform:methanol (1:1) from which fifteen fractions of $8 \mathrm{~mL}$ were collected and then analyzed and joined through analytical TLC. The sub-fraction 10-11 (0.015 g), washing with acetone gave a yellow solid codified as CG-02 (0.015 g).

\section{RESULTS AND DISCUSSION}

The ${ }^{1} \mathrm{H}$ NMR spectrum of compound 1 showed three protons at $\delta 2.76(1 \mathrm{H}, \mathrm{dd}, J=17.3,3.2 \mathrm{~Hz}), 3.09$ $(1 \mathrm{H}, \mathrm{dd}, J=17.3,13.0 \mathrm{~Hz})$ and $5.35(1 \mathrm{H}, \mathrm{dd}, J=13.0,3.2$ $\mathrm{Hz}$ ), typically assignable to $\mathrm{H}-3$ and $\mathrm{H}-2$ of a flavanone skeleton, which was indicated also in the ${ }^{1} \mathrm{H}$ NMR of CG$02[\delta 2.68(1 \mathrm{H}, \mathrm{dd}, J=17.0,3.0 \mathrm{~Hz}), 3.06(1 \mathrm{H}, \mathrm{dd}, J=$
$17.0,12.5 \mathrm{~Hz})$ and $5.26(\mathrm{dd}, J=12.5,3.0 \mathrm{~Hz})]$. In addition, signals for four protons at $\delta 6.93(2 \mathrm{H}, \mathrm{d}, J=8.7 \mathrm{~Hz})$ and $7.38(2 \mathrm{H}, \mathrm{d}, J=8.7 \mathrm{~Hz})]$ assignable to the aromatic protons of a 4-monosubstituted B-ring for $\mathbf{1}$ as well three protons at $\delta 6.78(2 \mathrm{H}, \mathrm{s})$ and $6.91(1 \mathrm{H}, \mathrm{sl})$ assignable to the aromatic protons of a 3,4-disubstituted B-ring for 2 . A downfield proton at $\delta 12.01$ (CG-01) and $\delta 12.1$ (CG-02, DMSO) assignable to $\mathrm{C} 5-\mathrm{OH}$ chelated to $\mathrm{C}-4$ carbonyl, and two additional aromatic protons at $\delta 6.93(1 \mathrm{H}, \mathrm{d}, J=$ $8.7 \mathrm{~Hz})$ and $7.38(1 \mathrm{H}, \mathrm{d}, J=8.7 \mathrm{~Hz}), \delta 5.87(1 \mathrm{H}, \mathrm{d}, J=$ $2.2 \mathrm{~Hz})$ and $5.89(1 \mathrm{H}, \mathrm{d}, \mathrm{J}=2.2 \mathrm{~Hz})$ were observed for $\mathbf{1}$ and 2, respectively, could be assigned to 6 and 7 aromatics protons of the A-ring. Furthermore, two methoxy signals appeared at $\delta 3.78(3 \mathrm{H}, \mathrm{s}), 3.81(3 \mathrm{H}, \mathrm{s})$ of compound 1. These spectroscopic data suggested that compound $\mathbf{1}$ and 2 were 5-hydroxyflavanones substituted with two methoxy groups and three hydroxyl groups, respectively. The ${ }^{13} \mathrm{C}$ NMR spectra analysis of $\mathbf{1}$ and $\mathbf{2}$ showed signals for 17 and 15 carbons, comprising two methoxy, one methylene, seven methynes and seven non-protonated carbons to $\mathbf{1}$ and one methylene, six methynes and eight non-protonated carbons to 2 . The analysis of these data sets with the spectra of HMQC, HMBC and NOESY, as well as comparison with literature data (Agrawal, 1989), has identified $\mathbf{1}$ as 5-hydroxy-4',7-dimethoxyflavanone (narigenin-4',7dimethyl ether) and 2 as 3',4',5,7-tetrahydroxyflavanone (eriodictyol), with yielding of $0.00025 \%$ and $0.00015 \%$, respectively

Narigenin-4',7-dimethyl ether (1): NMR ${ }^{1} \mathrm{H}(200 \mathrm{MHz}$, $\left.\mathrm{CDCl}_{3}\right) 2.76$ (H-3a, dd, $\left.J=3.2 ; 17.3\right), 3.09$ (H-3b, dd, $J$ $=13.0 ; 17.3), 3.78\left(\mathrm{OCH}_{3}-7, \mathrm{~s}\right), 3.81\left(\mathrm{OCH}_{3}-4, \mathrm{~s}\right), 5.35$ $(\mathrm{H}-2, \mathrm{dd}, J=3.2,13.0), 6.02(\mathrm{H}-8, \mathrm{~d}, J=2.3), 6.05$ (H-6, d, $J=2.3), 6.93$ (H-5', d, $J=8.7), 7.38$ (H-6', d, J = 8.7), 12.01 (s, OH-5). NMR ${ }^{13} \mathrm{C}\left(50 \mathrm{MHz}, \mathrm{CDCl}_{3}\right): 43.2$ (C-3), $55.4\left(\mathrm{OCH}_{3}\right), 55.7\left(\mathrm{OCH}_{3}\right), 79.0(\mathrm{C}-2), 94.2(\mathrm{C}-8), 95.1$ (C-6), 103.1 (C-10), 114.2 (C-3', 5'), 127.7 (C-2', 6'), 130.4 (C-1'), 160.0 (C-4'), 162.9 (C-9), 164.1 (C-5), 168.0 (C-7), 196.0 (C-4).

Eriodictyol (2): NMR ${ }^{1} \mathrm{H}(200 \mathrm{MHz}, \mathrm{MeOD}) 2.68$ (H-3a, $\mathrm{dd}, J=3.0 ; 17.0), 3.06$ (H-3b, dd, $J=12.5,17.0), 5.26$ $(\mathrm{H}-2, \mathrm{dd}, J=3.0,12.5), 5.87$ (H-8, d, $J=2.2), 5.89$ (H-6, d, $J=2.2), 6.78$ (H-5', H-6', 2H, s), 6.91 (H-2', 1H, sl). NMR ${ }^{13} \mathrm{C}$ : 44.1 (C-3), 80.5 (C-2), 96.2 (C-8), 97.0 (C-6), 103.3 (C-10), 114.7 (C-2'), 116.2 (C-5'), 119.3 (C-6'), 131.8 (C-1'), 146.5 (C-3'), 146.9 (C-4'), 164.9 (C-9), 165.4 (C-5), 168.4 (C-7), 197.8 (C-4).

The literature reports the isolation of only sixteen flavanones from Boraginaceae. The flavanones were isolated previously from genera Heliotropium, Cordia and Echiochilon. The majority of flavanones were obtained from the genus Heliotropium, on six species. In Echiochilon only E. fruticosum showed data from flavanones and in Cordia, two glycosides flavanones 
were previously isolated. The compounds obtained in this work were reported in Boraginaceae family in only one species $H$. stenophyllum. The flavanones isolated from genera Cordia and Heliotropium are preferably 3', 4', 5, 7, -tetraoxigenated (Chart 1).<smiles>[R]c1cc(O)c2c(c1)O[C@@H](c1ccc([R])c([R])c1)CC2=O</smiles>

(1) $\mathrm{R}_{1}=\mathrm{R}_{3}=\mathrm{OCH}_{3}, \mathrm{R}_{2}=\mathrm{H}$

(2) $R_{1}=R_{2}=R_{3}=O H$

\section{CONCLUSION}

This paper indicates that in Boraginaceae family the genera Heliotropium, Cordia and Echiochilon, until the present moment, are the only ones producing flavanones as well as reports the first flavanones aglycones from Cordia.

\section{ACKNOWLEDGEMENTS}

The authors wish to express their gratitude to Vicente Carlos de Oliveira Costa of the Laboratório de Tecnologia Farmacêutica, Universidade Federal da Paraíba, for providing the NMR spectra and CNPq/ IMSEAR for financial support. A sincere thanks is also due to NAPRALERT.

Chart 1. Distribution to flavanones in Boraginaceae family.

\begin{tabular}{|c|c|c|}
\hline Compound & Specie & Reference \\
\hline Hesperetin-7-O- $\alpha$-L-rhamnoside & Cordia obliqua & $\begin{array}{l}\text { Chauhan et al., } 1978 \\
\text { Tiwari et al., } 1979\end{array}$ \\
\hline Hesperidin & $\begin{array}{l}\text { C. francisci } \\
\text { C. martinicensis } \\
\text { C. myxa } \\
\text { C. serratifolia }\end{array}$ & Ficarra et al., 1995 \\
\hline 7-hydroxy-flavanone & Heliotropium indicum & Singh et al., 2003 \\
\hline 4',5-Dihydroxy-3',5',7-trimethoxyflavanone & H. megalanthun & Urzua et al., 2000 \\
\hline 5-Hidroxy-3',4',5', 7-tetramethoxyflavanone & H. megalanthum & Urzua et al., 2000 \\
\hline Eriodictyol & H. stenophyllum & Wollenweber et al., 2002 \\
\hline Eriodictyol-3',7-dimethyl ether & $\begin{array}{l}\text { H. chenopodiaceum var. } \\
\text { chenopodiaceum }\end{array}$ & Urzua et al., 1998 \\
\hline Eriodictyol-7-methyl ether & H. sinuatum & $\begin{array}{l}\text { Torres et al., } 1996 \\
\text { Modak et al., } 2005\end{array}$ \\
\hline Hesperetin & H. sinuatum & $\begin{array}{l}\text { Torres et al., } 1996 \\
\text { Modak et al., } 2004\end{array}$ \\
\hline Pinocembrim & $\begin{array}{l}\text { H. sinuatum } \\
\text { H. stenophyllum }\end{array}$ & $\begin{array}{l}\text { Torres et al., } 1996 \\
\text { Villarroel \& Urzua, } 1990 \\
\text { Wollenweber et al., } 2002\end{array}$ \\
\hline Pinocembrim-7-glycoside & Echiochilon fruticosum & Hammami et al., 2004 \\
\hline \multirow[t]{2}{*}{ Naringenin } & $\begin{array}{c}\text { H. chenopodiaceum var. } \\
\text { chenopodiaceum } \\
\text { H. chenopodiaceum var. ericoideum }\end{array}$ & Urzua et al., 1998 \\
\hline & H. stenophyllum & $\begin{array}{l}\text { Villarroel \& Urzua, } 1990 \\
\text { Wollenweber et al., } 2002\end{array}$ \\
\hline Naringenin-5-methyl ether & $\begin{array}{l}\text { E. fruticosum } \\
\text { H. indicum }\end{array}$ & $\begin{array}{c}\text { Hammami et al., } 2004 \\
\text { Singh et al., } 2003\end{array}$ \\
\hline Naringenin-7-methyl ether-4'-acetyl & H. stenophyllum & Wollenweber et al., 2002 \\
\hline Naringenin-4',7-dimethyl ether & H. stenophyllum & Wollenweber et al., 2002 \\
\hline Sakuranetin & $\begin{array}{c}\text { H. chenopodiaceum var. ericoideum } \\
\text { H. stenophyllum }\end{array}$ & $\begin{array}{c}\text { Urzua et al., } 1998 \\
\text { Wollenweber et al., } 2002\end{array}$ \\
\hline
\end{tabular}




\section{REFERENCES}

Asprey GF, Thornton P 1955. Medicinal Plants of Jamaica III. $W$ Indian Med J 4: 69-82.

Agrawal, PK 1989. ${ }^{13} \mathrm{C}$ - NMR of flavonoids. Amsterdam: Elsevier.

Chauhan JS, Srivastava SK, Sultan M 1978. Lupa-20,29-ene$3-O-\beta-\mathrm{D}$-maltoside from the roots of Cordia obliqua. Phytochemistry 17: 1005-106.

Feng PC, Haynes LJ, Magnus KE, Plimmer JR, Sherrat HAS 1962. Pharmacological screening of some west Indian medicinal plants. J Pharm Pharmacol 14: 556-561.

Ficarra R, Ficarra P, Tommasini S, Calabro ML, Ragusa S, Barbera R, Rapisarda A 1995. Leaf extracts of some Cordia species: analgesic and anti-inflammatory activities as well as their chromatographic analysis. Farmaco 50: $245-256$

Hammami S, Ben Jannet H, Bergaoui A, Ciavatta L, Cimino G, Mighri Z 2004. Isolation and structure elucidation of a flavanone, a flavanone glycoside and vomifoliol from Echiochilon fruticosum growing in Tunisia. Molecules 9: 602-608.

Menezes JESA, Lemos TLG, Pessoa ODL, Braz-Filho R, Montenegro RC, Wilke DV, Costa Lotufo LV, Pessoa C, Moraes MO, Silveira ER 2005. A Cytotoxic Meroterpenoid Benzoquinone from Roots of Cordia globosa. Planta Med 71: 54-58.

Menezes JESA, Lemos TLG, Silveira ER, Pessoa ODL, Santiago GMP, Nascimento RF 2006. Chemical composition and larvicidal activity of the essential oil from leaves of Cordia globosa (Jacq.) H.B.K. from northeastern Brazil. $J$ Essent Oil Res 18: 253-255.

Modak B, Torres R, Wilkens M, Urzua A 2004. Antibacterial activity of compounds isolated of the resinous exudates from Heliotropium sinuatum on phytopathogenic bacteria. J Chilean Chem Soc 49: 1-3.

Modak B, Contreras ML, Nilo-Gonzáles F, Torres R 2005. Structure-antioxidante activity relationships of flavonoids isolated from the resinous exudate of Heliotropium sinuatum. Bioorg Med Chem Lett 15: 309-312.

Oliveira JCS, Camara CAG, Schwartz MOE 2007. Volatile constituents of the stem and leaves of Cordia species from mountain forests of Pernambuco (north-eastern Brazil). J Essent Oil Res 19: 444-448.

Stevens PF 2001. Angiosperm Phylogeny Website. Version 7, May 2006 [and more or less continuously updated since]. http://www.mobot.org/MOBOT/research/APweb/

Silva SAS 2004. Investigação fitoquímica de espécies do gênero Cordia L. da flora paraibana (Boraginaceae). João Pessoa, 278p. Tese de Doutorado - Programa de PósGraduação em Produtos Naturais e Sintéticos Bioativos, Universidade Federal da Paraíba.

Silva SAS, Rodrigues MSL, Agra MF, Da-Cunha EVL, BarbosaFilho JM, Silva MS 2004. Flavonoids from Cordia globosa. Biochem Syst Ecol 32: 359-361.

Singh JP, Pandey DP, Pandey MB, Singh A, Singh R 2003. Constituents of Heliotropium indicum. Oriental J Chem 19: 723-724.

Tiwari KP, Srivastava SS 1979. Chemical investigation of stem bark of Cordia obliqua. Planta Med 36: 191-192.

Torres R, Modak B, Villarroel L, Urzua A, Delle Monache F, Sanchez-Ferrando F 1996. Flavonoids from resinous exudate of Heliotropium sinuatum. Bol Soc Chil Quim 41: 195-197.

Urzua A, Modak B, Villarroel L, Torres R, Andrade L 1998. Comparative flavonoid composition of the resinous exudate from Heliotropium chenopodiaceum var. chenopodiaceum and $H$. chenopodiaceum var. ericoideum. Biochem Syst Ecol 26: 127-130.

UrzuaA, Villarroel L, Torres R, Teillier S 2000. External flavonoids from Heliotropium megalanthum and $H$. huascoense (Boraginaceae). Chemotaxonomic considerations. Bol Soc Chil Quim 45: 23-29.

Villarroel L, Urzua M 1990. Secondary metabolites from the resinous exudate of Heliotropium stenophyllum. Bol Soc Chil Quim 35: 309-311.

Wollenweber E, Wehde R, Dör M, Stevens JF 2002. On the ocurrence of exudates flavonoids in the Borage family (Boraginaceae). Z Naturforsch C 57: 445-448. 